\title{
TERMS AND ABBREVIATIONS
}

\section{Note on Terms}

There is no adequate English term with which to designate the practitioners of the faith discussed in this book. The word "eunuch" (of which there exists the Russian "evnukh") does not convey the specificity of this case. Castrati are singers; castrate is a verb. Self-castrator is awkward and ambiguous. I have therefore chosen to use the Russian names "Skoptsy" (plural), "Skopets" (masculine singular). In violation of Russian grammar, I use the word "Skoptsy" not only as a noun but as an adjective (as, for example, in the phrase "the Skoptsy way of life"). The name of the faith as a whole is "Skopchestvo."

Skoptsy authors make frequent mistakes of grammar, spelling, and punctuation, of which they were themselves painfully aware. In translation, I have tried to convey the expressive quality of their prose but cannot always preserve their errors.

\section{Abbreviations}

Archival citations use the conventional abbreviations: collection (fond $=\mathrm{f}$.), inventory (opis $=$ op.), carton (karton = k.), file(s) (delo, dela $=\mathrm{d}$. or edinitsa khraneniia $=\mathrm{ed} . \mathrm{khr}$.), sheet(s) $($ list, listy $=1$.), and verso (oborot $=\mathrm{ob}$.).

The following abbreviations are used in the notes:

ARAN Arkhiv rossiiskoi akademii nauk (Archive of the Russian Academy of Sciences), St. Petersburg

GMIR Gosudarstvennyi muzei istorii religii (State Museum of the History of Religion), St. Petersburg 
OR-RGB Otdel rukopisei, Rossiiskaia gosudarstvennaia biblioteka (Manuscript Division, Russian State Library), Moscow

RGIA Rossiiskii gosudarstvennyi istoricheskii arkhiv (Russian State Historical Archive), St. Petersburg

Chteniia Chteniia vimperatorskom obshchestve istorii i drevnostei rossiiskikh pri Moskovskom universitete 


\section{CASTRATION \\ AND THE HEAVENLY \\ KINGDOM}


